Crop Breeding and Applied Biotechnology 13: 186-193 2013

Brazilian Society of Plant Breeding. Printed in Brazil

ARTICLE

\title{
Reproductive characteristics of citrus rootstocks grown under greenhouse and field environments
}

Divanilde Guerra $^{1 *}$, Maria Teresa Schifino Wittmann ${ }^{2}$, Sérgio Francisco Schwarz ${ }^{1}$, Paulo Vitor Dutra de Souza ${ }^{1}$ and Samanta Siqueira de Campos ${ }^{1}$

Received 11 October 2012

Accepted 06 September 2013

\begin{abstract}
The aim of the present study was to evaluate the possible effect of environmental factors on meiosis, meiotic index, pollen viability and in vitro germination of pollen from stock plants of the rootstocks Trifoliate, 'Swingle', 'Troyer', 'Fepagro C13', 'Fepagro C37' and 'Fepagro C41' grown in a protected environment in comparison with stock plants grown in the field. The results showed that values for the characteristics analyzed in 2008, 2009 and 2010 were always higher in the field than in the greenhouse conditions. In the field, the average of normal meiotic cells was $60.05 \%, 44.44 \%$ and $60.12 \%$, respectively, and in the greenhouse, $52.75 \%, 30.95 \%$ and $52.82 \%$, respectively. Mean pollen viability in the field was $90.28 \%, 56.23 \%$ and $74.74 \%$, and, in the greenhouse, $64.25 \%, 41.41 \%$ and $66.71 \%$, respectively. As temperature oscillations were higher in the greenhouse than in the field, we suggest that this negatively affects the reproductive characteristics analyzed.
\end{abstract}

Key words: Citriculture, meiotic behavior, pollen fertility, pollen germination.

\section{INTRODUCTION}

Among fruits for in natura consumption, citrus fruits are in first place in regard to production volume, and citriculture stands out worldwide as one of the most important agricultural and agroindustrial activities (Boteon and Neves 2005, FAO 2012). The fruits are also used for industrialization (Donadio et al. 2005). Higher citrus production as compared to other fruit crops is based on cultivated area and on the increasing use of productive scion and rootstock cultivars adapted to local environmental conditions and resistance to diseases and pests (Boteon and Neves 2005, Donadio et al. 2005, Hussain et al. 2011).

The choice of a rootstock is of extreme importance as it may affect several characteristics of the scion plant and fruits. Factors such as climate, soil, scion variety, management and good plant health conditions must be considered (Pompeu Junior 2005). In order to assure genetic and plant health conditions, it is better if rootstock plants are grown in protected environments (greenhouses) from buds or seeds from certified stock plants (Maciel et al. 2008). Stock plants from seeds do not necessarily need to be grown under protected conditions, but this practice assures healthier plants (Carvalho et al. 2000). In citrus, rootstock mother plants should have good production of viable seeds in order to ensure a large number of plants produced (Moreira et al. 2010). Even if reproduction is mainly by nucellar embryony, viable pollen is necessary for endosperm formation to ensure embryo nutrition and development (Koltunow 1993). Environmental factors in greenhouses may hinder reproductive characteristics and therefore seed and fruit production. According to Thakur et al. (2010) and Hedhly (2011), environmental stresses in plants during reproductive stages may be detrimental to the meiotic process and to viable pollen production. The initial stages of development of meiotic cells are most sensitive to stresses that also affect tapetum cells, therefore hindering cell nutrition and anther development, leading to pollen abortion and unviable pollination (Boyer and McLaughlin 2007).

The aim of the present study was to evaluate the possible effect of environmental factors on meiosis, meiotic index, pollen viability and in vitro germination of stock plants of citrus rootstocks grown in a protected environment in comparison with plants grown in the field.

\footnotetext{
${ }^{1}$ Universidade Federal do Rio Grande do Sul (UFRGS), Faculdade de Agronomia, Departamento de Horticultura e Silvicultura, Avenida Bento Gonçalves, 7712, 91.501970, Porto Alegre, RS, Brazil. *Email: divanildeguerra@yahoo.com.br.

${ }^{2}$ UFRGS, Departamento de Plantas Forrageiras e Agrometeorologia
} 


\section{MATERIAL AND METHODS}

The rootstocks Trifoliate (Poncirus trifoliata (L.) Raf,), Citrumeleiro 'Swingle' (Citrus paradisi Macf. x P. trifoliata) and Citrangeiro 'Troyer' (C. sinensis Osb. x P. trifoliata), widely used in citrus orchards in Brazil, as well as three new hybrids (C. sinensis x P. trifoliata), 'Fepagro C13' 'Fepagro $\mathrm{C} 37$ ' and 'Fepagro C41', which have potential in diversifying rootstocks in citrus orchards, were used in this study.

Flower buds in several stages of development were collected in the field at Fazenda Panoramas Citros, Butiá, Rio Grande do Sul, Brazil (lat 29 $57^{\prime}$ S, long $51^{\circ} 40^{\prime} \mathrm{W}$ ), and under a protected environment at EEA-UFRGS (Estação Experimental Agronômica, Universidade Federal do Rio Grande do Sul), Eldorado do Sul, Rio Grande do Sul, Brazil (lat $30^{\circ} 29^{\prime} \mathrm{S}$, long $51^{\circ} 06^{\prime} \mathrm{W}$ ). The plants in the field were exposed to natural climatic conditions. The protected environment was a greenhouse with a metallic structure and plastic roof. The plants were grown in $100 \mathrm{~L}$ capacity pots with a substrate composed of soil, acacia bark residue and carbonized rice hull (2:2:1-v:v:v), with daily drip irrigation. 'Fepagro C41' (C. sinensis x P. trifoliata) was only studied under greenhouse conditions, as no plants of this rootstock were available in the experimental field.

Temperature was monitored throughout the flowering period by a meteorological station (EEA-UFRGS) in the field and by a thermohygrograph in the greenhouse.

For cytogenetic analyses, flower buds were collected in 2008, 2009 and 2010, fixed in ethanol:acetic acid (3:1) for $24 \mathrm{~h}$ and stored in $70 \%$ ethanol in a freezer. Slides were prepared by squashing and staining in $2 \%$ propionic carmine all the anthers of a given flower bud.

Meiotic analysis was performed on ten flower buds per rootstock per environment per year; the slides were prepared with all the anthers of each flower bud. Ten replications for each rootstock and location were evaluated. All available pollen mother cells of any meiotic phase were analyzed. Cells with only bivalents (diakinesis and metaphase I) and regular disjunction (telophases and anaphases I and II) were considered as normal. Those with univalents, trivalents, quadrivalents and other associations (diakinesis and metaphase I) or with bridges, laggards and unequal disjunction (telophases and anaphases I and II) were recorded as abnormal.

Meiotic index, percentage of normal pollen tetrads, was determined using ten flower buds from a total of ten replications per rootstock and location, and 1000 post-meiotic products per rootstock per environment per year. Tetrads with four equal-sized cells were considered as normal, and any variant as abnormal.
Pollen viability was determined in ten flower buds. Slides were prepared with all the anthers of each flower bud. Ten replications for each rootstock and location were evaluated. A total of 10,000 mature pollen grains per rootstock per location per year were evaluated. Well-stained pollen grains were considered viable (Figure 1i), and those unstained, weakly stained or empty as unviable (Figure 1r).

Pollen in vitro germination was analyzed in 2010, using the Sahar and Spiegel-Roy (1984) culture medium (1\% agar, $15 \%$ sucrose, $100 \mathrm{ppm} \mathrm{H}_{3} \mathrm{BO}_{3}, 1000 \mathrm{ppm} \mathrm{Ca}\left(\mathrm{NO}_{3}\right) .4 \mathrm{H}_{2} \mathrm{O}$, $300 \mathrm{ppm} \mathrm{MgSO}_{4} \cdot 7 \mathrm{H}_{2} \mathrm{O}$ and $100 \mathrm{ppm} \mathrm{KNO}_{3}$ ). Four flower buds of each genotype under field and greenhouse conditions were evaluated, with four replications per rootstock and location. Freshly collected pollen grains were distributed in slides with culture medium and kept in a BOD (Biochemical Oxygen Demand) germination chamber at $25 \pm \mathbf{2}^{\circ} \mathbf{C}$, for 24 hours. Germination was analyzed in 1000 grains per rootstock per location. Pollen grains with a pollen tube bigger than pollen grain diameter were considered as germinated. In 40 germinated grains, pollen tube length (from the exine to the tube apex) was measured.

Meiotic behavior, meiotic index, pollen viability, pollen in vitro germination and pollen tube length analysis were performed directly under an optical microscope, and images were recorded by photomicrographs or digital image capturing. Results were analyzed by the Tukey test at 5\% with the aid of SAS software.

\section{RESULTS}

Through analysis of meiotic cells, it was confirmed that all rootstocks were diploid ( $n=9$, therefore $2 n=18$ ) (Figure $1 \mathrm{a}$ and $\mathrm{b}$ ). All phases of meiosis I and II were recorded, both for regular and irregular behavior (Figure 1).

Variation in percentages of normal cells was observed among rootstocks grown under field and greenhouse conditions, as well as among years (Table 1). Percentages of normal cells were always higher in plants under field conditions than those under greenhouse conditions. Under field conditions, percentages of normal cells for Trifoliate were $62.77 \%, 48.48 \%$ and $61.78 \%$ in 2008, 2009 and 2010 , respectively, and, under greenhouse conditions, $58.52 \%$, $35.29 \%$ and $55.93 \%$ in 2008,2009 and 2010 , respectively. All other rootstocks performed in the same way (Table 1), with higher percentage of normal cells under field conditions than under greenhouse conditions. Considering years, values were similar for all rootstocks under field and greenhouse conditions for the years 2008 and 2010. In 2009, percentages of normal cells were lower than for 2008 and 2010 for all the rootstocks in the field and in the greenhouse (Table 1). The averages of normal cells for all rootstocks were $60.05 \%$ and $60.12 \%$ in 2008 and 2010 , respectively, and $44.44 \%$ in 


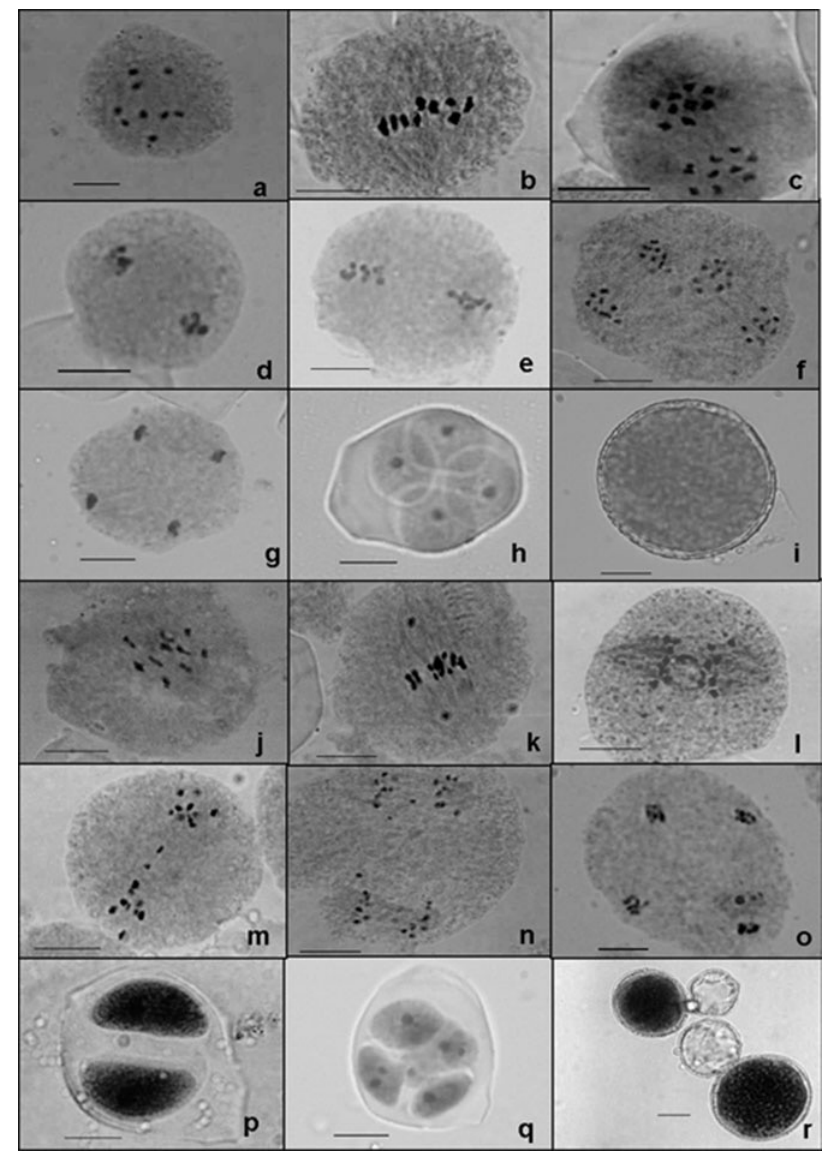

Figure 1. Normal and irregular cells from meiosis I to pollen. a) Diakinesis with 9 bivalents (II); b) Metaphase I with 9II; c) Anaphase I with normal disjunction (9/9); d) Telophase I; e) Metaphase II; f) Anaphase II with normal disjunction (9/9/9/9); g) Telophase II; h) tetrad; i) mature viable pollen grain; j) Diakinesis with 8 II and 2 I (univalents); k) Metaphase I with 6 II, 2 I and 1 IV (quadrivalent); 1) Anaphase I with laggards; m) Telophase I with laggards; n) Anaphase II with irregular disjunction; o) Telophase II with micronuclei; p) Dyad; q) Polyad; r) Unviable (not stained) pollen grains. Scale bar $=10 \mu \mathrm{m}$.

2009 under field conditions. Under greenhouse conditions, the averages were $52.75 \%$ and $52.82 \%$ in 2008 and 2010 , respectively, and 30.95\% in 2009 (Table 1).

Besides normal pollen tetrads (Figure $1 \mathrm{~h}$ ), dyads (Figure $1 \mathrm{p}$ ), polyads (Figure $1 \mathrm{q}$ ) and microcytes were observed during meiotic index analyses. Differences between plants under field and greenhouse conditions, as well as among years were also observed, with higher values being found under field conditions (Table 2). Under field conditions, the highest meiotic indexes were observed for Trifoliate: $64.24 \%$ in $2008,52.35 \%$ in 2009 and $64.09 \%$ in 2010 , while in the greenhouse the values were lower, $62.14 \%$ in 2008 , $35.29 \%$ in 2009 and $62.63 \%$ in 2010 . The same differences between field and greenhouse were observed for all the other genotypes (Table 2). Among years, under field conditions, the averages were $61.28 \%$ in $2008,46.31 \%$ in 2009 and
$61.28 \%$ in 2010 , and, under greenhouse conditions, $54.26 \%$ in $2008,31.75 \%$ in 2009 and $54.47 \%$ in 2010 (Table 2).

Trifoliate presented the highest percentages of viable pollen grains under both field and greenhouse conditions. In the field, the values were $95.12 \%$ in $2008,63.47 \%$ in 2009 and $97.76 \%$ in 2010 and, in the greenhouse, $68.13 \%$, $49.45 \%$ and $78.40 \%$ in 2008,2009 and 2010 , respectively (Table 3). Higher values for pollen fertility in the field were observed for all the other genotypes (Table 3). The averages for all rootstocks among years were $90.28 \%$ in $2008,56.23 \%$ in 2009 and $74.74 \%$ in 2010 in the field, and $64.25 \%$ in $2008,41.41 \%$ in 2009 and $66.71 \%$ in 2010 in the greenhouse (Table 3). Low frequencies of pollen grains bigger than normal ones were observed, but they were not considered as unreduced grains, as they were not 30 to $40 \%$ larger than the normal ones, a criterion normally used to classify unreduced gametes (Hermsen 1984). Therefore, for meiotic behavior, meiotic index and pollen fertility, plants under field conditions performed better that those under greenhouse conditions, and lower values for all genotypes in both conditions were observed in 2009 .

Pollen in vitro germination and pollen tube length for all plants were higher under field than under greenhouse conditions. Averages for pollen in vitro germination for all genotypes were $41.81 \%$ in the field and $36.32 \%$ in the greenhouse and, for pollen tube length, $45.59 \mu \mathrm{m}$ in the field and $21.78 \mu \mathrm{m}$ in the greenhouse (Table 3).

\section{DISCUSSION}

For all the characteristics studied, plants grown under field conditions performed better than those under greenhouse conditions (Tables 1, 2 and 3), leading to the conclusion that environmental factors in the protected environment negatively affect the reproductive characteristics analyzed. In the greenhouse, the minimum and maximum temperature values were higher and the oscillations more marked than in the field (Figure 2). According to Nayyar et al. (2005), Zinn et al. (2010) and Hedhly (2011), sudden variations in temperature in the reproductive stage, even for a short period, are enough to damage the cells and hinder meiosis and pollen fertility. In several plants, such as rice (Oryza sativa L.) (Oliver et al. 2005), peach (Prunus persica L) (Kozai et al. 2004, Nava et al. 2009), apricot (Prunus armeniaca L.) (Rodrigo and Herrero 2002), citrus (Citrus unshiu) (Takagi et al. 1982), cherry (Prunus avium L.) (Hedhly et al. 2007) and barley (Hordeum vulgare L.) (Sakata et al. 2000), unfavorable temperatures are reported to impair meiotic behavior and pollen fertility.

Cells with irregularities were already observed in meiosis I, corroborating Thakur et al. (2010) that environmental stresses are detrimental as of the first stages of meiosis. 
The abnormalities found at meiosis II, pollen tetrads and reduced pollen viability is in agreement with Chen et al. (2004) and Kamiri et al. (2011) that, in citrus, abnormalities at meiosis I lead to abnormalities in meiosis II, pollen tetrads and, therefore, low pollen viability. Agarwal (1987) also suggested that in citrus there is a positive correlation between frequency of univalents and pollen sterility. Abnormalities in the meiotic process, leading to reduced pollen viability, has been described in other plants, such as Zea mays, Paspalum (Paspalum spp.), triticale (x Triticosecale Wittmack), soybean (Glycine max) and brassicas (Brassica napus and B. Campestris) (Bione et al. 1999, Pagliarini 2000, Guerra et al. 2011).

The higher percentage of meiotic irregularities and lower pollen fertility observed in the greenhouse (Tables 1,2 and 3 ) may be a limiting factor in producing citrus rootstock mother plants from seeds in protected environments, due to the possible negative effect on seed production. Even considering that these plants reproduce by apomixis (Cameron and Soost 1969, Koltunow 1993), viable pollen grains are necessary for fertilization and endosperm development of the sexual embryo, therefore assuring the essential nutrients and hormones for nucellar embryo growth and viable seed formation (Koltunow 1993, Davies and Albrigo 1994, Spielman et al. 2003, Machado et al. 2005). Low percentage of viable pollen and, consequently, low seed production has been observed in orange, mandarin and lime by Moreira and Gurgel (1941) and Sellito-Boaventura and Pio (1989). The lower values for the characteristics analyzed in the present study in the greenhouse (Tables 1, 2 and 3) show that environmental factors in the greenhouse are negatively

Minimum and maximum temperature in the field

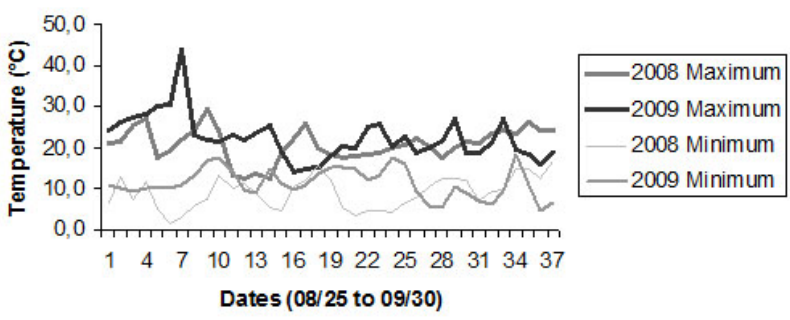

Minimum and maximum temperature in the greenhouse

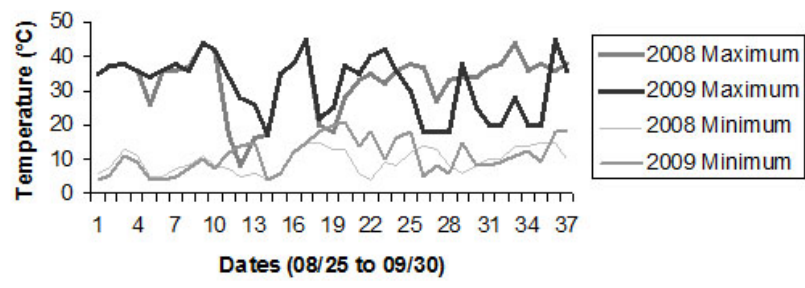

Figure 2. Minimum and maximum temperatures in the field and in the greenhouse from August 25 to September 30, 2008

Table 1. Meiosis in rootstocks under field and greenhouse conditions over three years

\begin{tabular}{|c|c|c|c|c|c|c|}
\hline Rootstock & $\begin{array}{l}\text { Number } \\
\text { of cells }\end{array}$ & $\begin{array}{l}\text { Normal cells } \\
(\%)\end{array}$ & $\begin{array}{l}\text { Number } \\
\text { of cells }\end{array}$ & $\begin{array}{l}\text { Normal cells } \\
(\%)\end{array}$ & $\begin{array}{l}\text { Number } \\
\text { of cells }\end{array}$ & $\begin{array}{l}\text { Normal cells } \\
(\%)\end{array}$ \\
\hline & 2008 & & 2009 & & 2010 & \\
\hline \multicolumn{7}{|l|}{ Field } \\
\hline Trifoliate & 188 & $62.77 \mathrm{aA}$ & 231 & $48.48 \mathrm{aA}$ & 225 & $61.78 \mathrm{aA}$ \\
\hline 'Swingle' & 180 & $57.22 \mathrm{cA}$ & 246 & $40.24 \mathrm{cA}$ & 226 & $57.52 \mathrm{bA}$ \\
\hline 'Fepagro C37' & 191 & $58.12 \mathrm{bcA}$ & 225 & $41.78 \mathrm{cA}$ & 235 & $59.15 \mathrm{abA}$ \\
\hline Averages & ----- & 60.05 & ----- & 44.44 & ----- & 60.12 \\
\hline \multicolumn{7}{|l|}{ Greenhouse } \\
\hline Trifoliate & 176 & $58.52 \mathrm{aB}$ & 170 & $35.29 \mathrm{aB}$ & 236 & $55.93 \mathrm{aB}$ \\
\hline 'Fepagro C37' & 275 & $51.64 \mathrm{bB}$ & 230 & $30.43 \mathrm{bcB}$ & 258 & $52.71 \mathrm{bB}$ \\
\hline 'Fepagro C41' & 221 & $45.70 \mathrm{c}$ & 219 & $28.31 \mathrm{c}$ & 270 & $46.30 \mathrm{c}$ \\
\hline Averages & ---- & 52.75 & ---- & 30.95 & ----- & 52.82 \\
\hline
\end{tabular}

Averages followed by the same lower case letter in the column do not differ significantly, for the same condition, by the Tukey test ( $\mathrm{p}>0.05$ ). Averages followed by the same capital letter in the column do not differ significantly in comparison with the same rootstock under different conditions by the Tukey test ( $\mathrm{p}>0.05$ ). 
D Guerra et al.

Table 2. Meiotic index (\%) in rootstocks under field and greenhouse conditions over three years

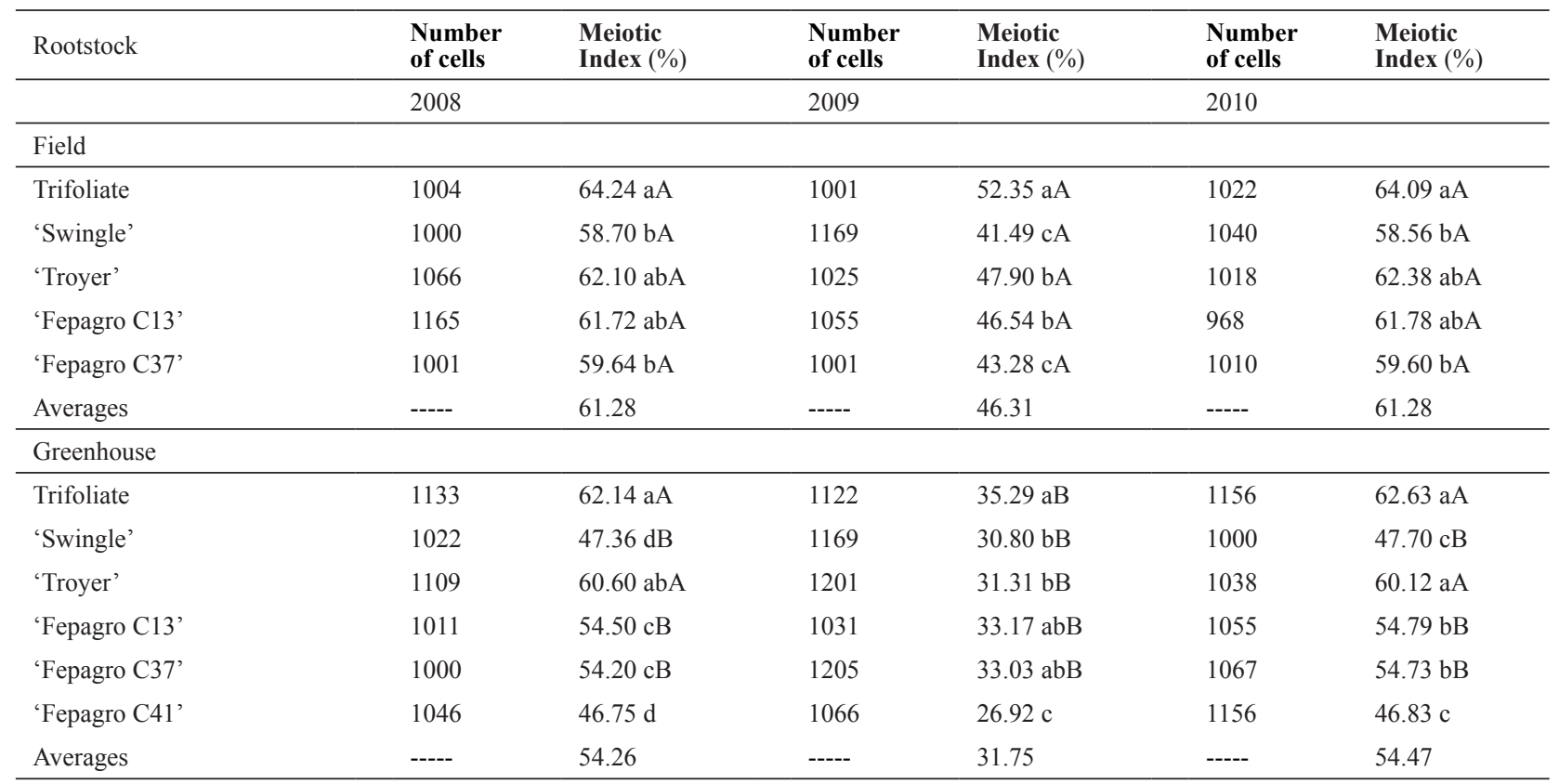

Averages followed by the same lower case letter in the column do not differ significantly, for the same condition, by the Tukey test ( $\mathrm{p}>0.05$ ). Averages followed by the same capital letter in the column do not differ significantly in comparison with the same rootstock under different conditions by the Tukey test ( $\mathrm{p}>0.05$ ).

Table 3. Pollen viability (\%) in rootstocks under field and greenhouse conditions over three years, and pollen in vitro germination and pollen tube length in rootstocks under field and greenhouse conditions in 2010

\begin{tabular}{|c|c|c|c|c|c|c|c|c|}
\hline \multirow[t]{2}{*}{ Rootstock } & \multicolumn{6}{|c|}{$\begin{array}{l}\text { Pollen fertility } \\
(\%)\end{array}$} & \multicolumn{2}{|c|}{ ollen in vitro germination } \\
\hline & $\begin{array}{l}\text { No. } \\
\text { cells }\end{array}$ & $\begin{array}{l}\text { Viability } \\
(\%)\end{array}$ & $\begin{array}{l}\text { No. } \\
\text { cells }\end{array}$ & $\begin{array}{l}\text { Viability } \\
(\%)\end{array}$ & $\begin{array}{l}\text { No. } \\
\text { cells }\end{array}$ & $\begin{array}{l}\text { Viability } \\
(\%)\end{array}$ & $\begin{array}{l}\text { Germin. } \\
(\%)\end{array}$ & $\begin{array}{l}\text { Tube Length } \\
(\mu \mathrm{m})\end{array}$ \\
\hline \multicolumn{9}{|l|}{ Field } \\
\hline Trifoliate & 10008 & $95.12 \mathrm{aA}$ & 10006 & $63.47 \mathrm{aA}$ & 10101 & $97.76 \mathrm{aA}$ & $47.49 \mathrm{aA}$ & $48.58 \mathrm{aA}$ \\
\hline ‘Troyer’ & 10126 & $93.11 \mathrm{abA}$ & 10068 & $59.55 \mathrm{bA}$ & 10199 & $79.52 \mathrm{bA}$ & $46.52 \mathrm{aA}$ & $46.70 \mathrm{abA}$ \\
\hline 'Fepagro C13' & 10122 & $90.47 \mathrm{bcA}$ & 10050 & $57.12 \mathrm{bcA}$ & 10115 & $77.22 \mathrm{bA}$ & $44.00 \mathrm{bA}$ & $45.98 \mathrm{abA}$ \\
\hline 'Fepagro C37' & 10119 & $87.24 \mathrm{cdA}$ & 10330 & $51.72 \mathrm{dA}$ & 10203 & $64.08 \mathrm{cA}$ & $35.12 \mathrm{cA}$ & $43.30 \mathrm{bA}$ \\
\hline Averages & ----- & 90.28 & ----- & 56.23 & ----- & 74.74 & 41,81 & 45.59 \\
\hline ‘Troyer’ & 10514 & $71.15 \mathrm{bB}$ & 10051 & $48.62 \mathrm{aB}$ & 10080 & $71.39 \mathrm{bB}$ & $41.56 \mathrm{bB}$ & $23.60 \mathrm{abB}$ \\
\hline 'Fepagro C13' & 10118 & $75.46 \mathrm{aB}$ & 10290 & $42.69 \mathrm{bB}$ & 10197 & $68.54 \mathrm{bcB}$ & $38.23 \mathrm{cB}$ & $23.17 \mathrm{abB}$ \\
\hline 'Fepagro C37' & 10024 & $65.31 \mathrm{cB}$ & 10226 & $38.41 \mathrm{cB}$ & 10159 & $61.11 \mathrm{cA}$ & $32.40 \mathrm{~dB}$ & $21.89 \mathrm{abcB}$ \\
\hline 'Fepagro C41' & 10231 & $53.42 \mathrm{~d}$ & 10126 & $32.60 \mathrm{~d}$ & 10196 & $62.83 \mathrm{c}$ & $31.18 \mathrm{e}$ & $19.24 \mathrm{c}$ \\
\hline Averages & ----- & 64.25 & ----- & 41.41 & ----- & 66.71 & 36.32 & 21.78 \\
\hline
\end{tabular}

Averages followed by the same lower case letter in the column do not differ significantly, for the same condition, by the Tukey test ( $\mathrm{p}>0.05$ ). Averages followed by the same capital letter in the column do not differ significantly in comparison with the same rootstock under different conditions by the Tukey test ( $\mathrm{p}>0.05$ ). 
affecting these characteristics. Abiotic stresses such as water deficiency, nutrition, light, salinity, pollution and temperature are known to impair meiosis and pollen viability (Lalonde et al. 1997, Saini 1997, Sun et al. 2004). In the present study, we suggest that the greater amplitude of temperature variation in the greenhouse compared with the field is the main factor responsible for the observed abnormalities (Figure 2, data for 2008 and 2009).

For pollen in vitro germination, the experimental temperature used $\left(25 \pm 2{ }^{\circ} \mathrm{C}\right)$ is the one described as ideal for pollen germination in citrus (Cavalcante et al. 2000, Distefano et al. 2012). Differences in pollen germination between plants grown in the greenhouse (lower values) and those grown in the field (higher values) were found (Table 3). Even though temperature in the greenhouse was not monitored in 2010, oscillations like those in 2008 and 2009 were expected, which could explain the lower values of pollen viability and therefore lower pollen germination. According to Srinivasan et al. (1999), temperature stress during pollen grain formation may impair accumulation of energy and nutrients such as carbohydrates and amino acids, reducing germination ability. In pepper (Capsicum annuиm L.), Aloni et al. (2001) found less pollen viability and germination under higher temperatures. Hedhly et al. (2004) in cherry (Prunus avium L.) and Nava et al. (2009) in peach (Prunus persica L.) observed lower pollen viability and germination in plants grown in protected environments compared with those grown in the field and associated their results with physiological damage caused by higher temperatures in the greenhouse.

Values for the characteristics analyzed were lower for both greenhouse and field in 2009 than in the other two years (Tables 1, 2 and 3). It may be concluded that in 2009 environmental conditions were more unfavourable in the greenhouse and in the field. Moreira and Gurgel (1941) already reported that different climatic conditions among years affect meiosis and pollen grain viability. Temperature variation and precipitation in the field during the flowering months (August and September), which was much higher in $2009(618.5 \mathrm{~mm})$ than in $2008(308.4 \mathrm{~mm})$ and 2010 $(304.9 \mathrm{~mm})$, may have affected the results. Therefore, the factor responsible for that remains to be identified.

\section{CONCLUSIONS}

There was an unfavourable effect of greenhouse conditions on meiosis, meiotic index, pollen viability and in vitro germination compared with field conditions. It is possible that the greater temperature variation in the greenhouse was the causative factor.

\section{ACKNOWLEDGMENTS}

To CAPES (Coordenação de Aperfeiçoamento de Pessoal de Nível Superior, Brazil) and CNPq (Conselho Nacional de Desenvolvimento Científico e Tecnológico, Brazil) for the scholarships and research grants to the authors.

\title{
Reproductive characteristics of citrus rootstocks grown under greenhouse and field environments
}

\begin{abstract}
Resumo - O objetivo do presente trabalho foi avaliar o possivel efeito dos fatores ambientais no processo meiótico, indice meiótico, viabilidade de pólen e germinação in vitro do pólen de plantas-matrizes dos porta-enxertos Trifoliata, 'Swingle', 'Troyer', 'Fepagro C13', 'Fepagro C37'e 'Fepagro C41' conduzidos em ambiente protegido em comparação com plantas-matrizes conduzidas a campo. Os resultados mostraram que os valores para as características analisadas em 2008, 2009 e 2010, foram sempre maiores no campo do que em casa-de-vegetação. A campo, a média de células meióticas normais foi de 60,05\%, 44,44\% e 60,12\%, respectivamente e em casa-de-vegetação foi de 52,75\%, 30,95\% e 52,82\%, respectivamente; a viabilidade média do pólen a campo foi de 90,28\%, 56,23\% e $74,74 \%$ e em casa-de-vegetação foi de $64,25 \%, 41,41 \%$ e 66,71\%, respectivamente. Como as oscilações de temperatura foram maiores na estufa que, no campo, é sugerido que esta afeta negativamente as características reprodutivas analisadas.
\end{abstract}

Palavras-chave: Citricultura, comportamento meiótico, fertilidade do pólen, germinação do pólen.

\section{REFERENCES}

Agarwal PK (1987) Cytogenetical investigations in Rutaceae II. Meiotic studies in three intergeneric hybrids of Citrus. Cytologia 52: 757-760.

Aloni B, Peet M, Pharr M and Karni L (2001) The effect of high temperature and high atmospheric $\mathrm{CO}_{2}$ on carbohydrate changes in bell pepper (Capsicum annuиm) pollen in relation to its germination. Physiologia Plantarum 112: 505-512.

Bione NCP, Pagliarini MS and Alves LA (2003) Further cytological characteristics of a male-sterile mutant in soybean affecting cytokinesis and microspore development. Plant Breeding 122: 244-247.

Boteon M and Neves EM (2005) Citricultura brasileira: aspectos econômicos in: Mattos Junior D, De Negre JD, Pio RM and Pompeu Juniro J (eds.) Citros. Instituto Agronômico e Fundag, Campinas, p.19-36.

Boyer JS and McLaughlin JE (2007) Functional reversion to identify controlling genes in multigenic responses: analysis of floral abortion. Journal of Experimental Botany 58: 267-277. 
D Guerra et al.

Cameron JW and Soost RK (1969) Characters of new populations of Citrus polyploids, and the relation between tetraploidy in the pollen parent and hybrid tetraploid progeny. In Chapman HD (ed.) Proceedings of the international citric symposium. University of California, Riverside, p. 199-205.

Carvalho AS, Silva JAA and Sempionato OR (2000) Produção de borbulhas certificadas de citros no Estado de São Paulo. Editora Funep, Jaboticabal, 26p.

Cavalcante HC, Schifino-Wittmann MT and Dornelles ALC (2000) Meiotic behaviour and pollen fertility in an open-pollinated population of "Lee" mandarin [Citrus clementina x (C. paradise x C. tangerina)]. Scientia Horticulturae 86: 103-114.

Chen CL, Guo WW, Yi HL and Deng XX (2004) Cytogenetic analysis of two interspecific Citrus allotetraploid somatic hybrids and their diploid fusion parents. Plant Breeding 123: 332-337.

Davies FS and Albrigo LG (1994) Citrus. Editora Cabi, Wallingford, 254p.

Distefano G, Hedhly A, Casas GL, Malfa SL, Herrero M and Gentile A (2012) Male-female interaction and temperature variation affect pollen performance in Citrus. Scientia Horticulturae 140: 1-7.

Donadio LC, Mourão Filho FAA and Moreira CS (2005) Centros de origem, distribuição geográfica das plantas cítricas e histórico da citricultura no Brasil. In Mattos Junior D, De Negre JD, Pio RM, Pompeu Junior J (eds.) Citros. Instituto Agronômico e Fundag, Campinas, p.1-18.

FAO. Faostat agriculture data, agricultural production, crops primary. Available at $<\underline{\mathrm{http}} / / / \mathrm{www}$.fao.org/> Accessed on May 10, 2012.

Guerra D, Pacheco MT and Federizzi LC (2011) Analysis of selffertilization and meiotic behavior of eleven Brazilian triticale cultivars at two sowing dates. Crop Breeding and Applied Biotechnology 11: $114-124$

Hedhly A, Hormaza JI and Herrero M (2004) Effect of temperature on pollen tube kinetics and dynamics in sweet cherry, Prunus avium (Rosaceae). American Journal of Botany 91: 558-564.

Hedhly A, Hormaza JI and Herrero M (2007) Warm temperatures at bloom reduce fruit set in sweet cherry. Journal of Applied Botany and Food Quality 81: 158-164.

Hedhly A (2011) Sensitivity of flowering plant gametophytes to temperature fluctuations. Environmental and Experimental Botany 74: 9-16.

Hermsen JG (1984) Mechanisms and genetics implications of 2n-gamete formation. Iowa State Journal of Research 58: 421-434.

Hussain S, Curk F, Ollitrault P, Morillon R and Luro F (2011) Facultative apomixis and chromosome doubling are sources of heterogeneity in citrus rootstock trials: Impact on clementine production and breeding selection. Scientia Horticulturae 130: 815-819.

Kamiri M, Stift M, Srairi I, Costantino G, El Moussadik A, Hmyene A, Bakry F, Ollitrault P and Froelicher Y (2011) Evidence for non-disomic inheritance in a Citrus interspecific tetraploid somatic hybrid between C. reticulata and C. limon using SSR markers and cytogenetic analysis. Plant Cell Reports 30: 1415-1425.
Koltunow AM (1993) Apomixis: Embryo sacs and embryos formed without meiosis or fertilization in ovules. The Plant Cell 5: 1425-1437.

Kozai N, Beppu K, Mochioka R, Boonprakob U, Subhadrabandhu S and Kataoka I (2004) Adverse effects of high temperature on the development of reproductive organs in 'Hakuho' peach trees. The Journal of Horticultural Science \& Biotechnology 79: 533-537.

Lalonde S, Beebe DU and Saini HS (1997) Early signs of disruption of wheat anther development associated with the induction of male sterility by meiotic-stage water deficit. Sex Plant Reproduction 10: $40-48$.

Machado MA, Cristofani-Yaly M, Amaral AM and Oliveira AC (2005) Genética, melhoramento e biotecnologia de citros. In Mattos Junior D, De Negre JD, Pio RM, Pompeu Junior J (eds.) Citros. Instituto Agronômico e Fundag, Campinas, p.221-277.

Maciel HS, Souza, PVD and Schafer G (2008) Viabilidade de borbulhas de citros coletadas de ambiente protegido e mantidas em frigoconservação. Revista Brasileira de Fruticultura 30: 241-245.

Moreira S and Gurgel JTA (1941) A fertilidade do pólen e sua correlação com o número de sementes em espécies e formas do gênero Citrus. Bragantia 1: 669-711.

Moreira RA, Ramos JD and Cruz MCM (2010) Caracterização de frutos e poliembrionia em sementes de 'flying dragon' e de híbridos de portaenxerto de citros. Revista Brasileira de Fruticultura 32: 486-492.

Nava GA, Dalmago GA, Bergamaschi H, Paniz R, Santos RP and Marodin GAB (2009) Effect of high temperatures in the pre-blooming and blooming periods on ovule formation, pollen grains and yield of 'Granada' peach. Scientia Horticulturae 122: 37-44.

Nayyar H, Bains TS, Kumar S and Kaur G (2005) Chilling effect during seed filling on accumulation of seed reserves and yield of chickpea. Journal of the Science of Food and Agriculture 85: 1925-1930.

Oliver SN, Van Dongen JT, Alfred SC, Mamun EA, Zhao X, Saini HS, Fernandes SF, Blanchard CL, Sutton BG, Geigenberger P, Dennis ES and Dolferus R (2005) Cold-induced repression of the rice antherspecific cell wall invertase gene OSINV4 is correlated with sucrose accumulation and pollen sterility. Plant, Cell \& Environment 28: 1534-1551.

Pagliarini MS (2000) Meiotic behavior of economically important plant species: the relationship between fertility and male sterility. Genetics and Molecular Biology 4: 997-1002.

Pompeu Junior J (2005) Porta-enxertos. In Mattos Junior D, De Negre JD, Pio RM, Pompeu Junior J (eds.) Citros. Fundag, Instituto Agronômico, Campinas, p.61-104.

Rodrigo J and Herrero M (2002) Effects of pre-blossom temperatures on flower development and fruit set in apricot. Scientia Horticulturae 92: 125-135.

Sahar N and Spiegel-Roy P (1984) In vitro germination of avocado pollen. Scientia Horticulturae 19: 886-888.

Saini HS (1997) Effects of water stress on male gametophyte development 
in plants. Sexual Plant Reproduction 10: 67-73.

Sakata T, Takahashi H, Nishiyama I and Higashitani A (2000) Effects of high temperature on the development of pollen mother cells and microspores in barley Hordeum vulgare L. Journal of Plant Research 113: $395-402$.

Selito-Boaventura YM and Pio RM (1989) Análise citogenética em três cultivares de laranja doce (C. sinensis (L.) Osbeck). Brazilian Journal of Genetics 12: 117-126.

Spielman M, Vinkenoog R and Scott RJ (2003) Genetic mechanisms of apomixis. Philosophical Transactions of Biological Science 358: 1095-1103.

Srinivasan A, Saxena NP and Johansen C (1999) Cold tolerance during early reproductive growth of chickpea (Cicer arietinum $\mathrm{L}$ ): genetic variation in gamete development and function. Field and Crop
Research 60: 209-222.

Sun K, Hunt K and Hauser BA (2004) Ovule abortion in Arabidopsis triggered by stress. Plant Physiology 135: 2358-2367.

Takagi T, Sawano I, Suzuki T and Okamoto S (1982) Effects of temperature before and after flowering on the development of flower and fruit in Citrus unshiu. Journal of the Japanese Society for Horticulture Science 51: 257-262.

Thakur P, Kumar S, Malik JA, Berger JD and Nayyar H (2010) Cold stress effects on reproductive development in grain crops: An overview. Environmental and Experimental Botany 67: 429-443.

Zinn KE, Tunc-Ozdemir M and Harper JF (2010) Temperature stress and plant sexual reproduction: uncovering the weakest links. Journal of Experimental Botany 61: 1959-1968. 